\title{
Examination of the Views of Juynboll Concerning Qur'anic Sciences
}

\author{
Hassan Rezaee Haftador ${ }^{1}$ \\ ${ }^{1}$ Hadith and Qur'anic Sciences Department, University of Tehran, Iran \\ Correspondence: Hassan Rezaee Haftador, Hadith and Qur'anic Sciences Department, University of Tehran, Iran. \\ E-mail: hrezaii@ut.ac.ir
}

Received: October 19, 2015

doi:10.5539/res.v8n1p45

\author{
Accepted: November 16, $2015 \quad$ Online Published: February 2, 2016 \\ URL: http://dx.doi.org/10.5539/res.v8n1p45
}

\begin{abstract}
Qur'anic studies examines issues related to understanding of the Qur' an. The orientalist Juynboll has examined some of the most important topics in Qur'anic studies including revelation, collection, and recitation of the Qur' an. The present study evaluates his ideas concerning these issues. This library study takes an analytic and critical approach to the topic at hand. Descriptive methods are also utilised. Though examination of the views of Juynboll concerning Qur'anic sciences is the focus of this endeavour, the views of Muslim scholars are also considered for completion of the study. Through examination of Juynboll's views on Qur' anic sciences, it is clear that he has conducted significant research on Islamic sources. However, his use of weak ( $d a$ i $f$ ) Islamic narratives has led to errors in some areas of the Qur' anic sciences.
\end{abstract}

Keywords: Juynboll, Qur' anic sciences, the Prophet of Islam, Qur'an

\section{Introduction}

The term Qur'anic sciences is a combination of the words Qur'anic and sciences. Sciences is a plural word meaning knowledge and the Qur'an is the main name of the Muslim scripture. Qur'anic sciences study the Qur' an as a knowable phenomenon. This discipline deals with a variety of topics, the most important of which include the manner of Qur' anic revelation, collection of the Qur' an, recitation of the Qur'an, lack of distortion in the Qur'an, relationships between Qur'anic verses such as nassikh and mansükh, muhkam and mutashäbih, and 'ām and khāṣ.

The aim of Qur'anic sciences is understanding of all aspects of the Qur' an (Sa 'î̀ī Rawshan, 2009, pp. 19-20; Zarqānī, 1995, vol. 1, p. 31). Orientalists have been studying the Qur' an for many years. They have published the results of their Qur'anic research in the form of scientific articles, books, and encyclopaedias (Rezaee Haftador, 2015, p. 33). Gautier H. A. Juynboll (1935-2010) is one such orientalist. The present study takes a descriptive and analytic approach to answer the following questions.

- What are the views of Juynboll with regard to Qur'anic sciences?

- To what extent are these views congruous with Islamic teachings?

\section{The Prophet of Islam's Forgetfulness of the Qur'an}

According to Juynboll, Muhammad, the Prophet of Islam, forgot parts of the Qur'an (Juynboll, 2002, vol. 2, p. 382 ).

This view is unacceptable due to the following reasons.

1) Prophet Muhammad would frequently warn Muslims about forgetting the Qur'an. The following Islamic traditions substantiate this fact.

a. 'Abd Allāh ibn Mas' ûd has quoted, The Prophet of Islam has stated, "How bad it is for one of you to say, 'I have forgotten a certain verse of the Qur' an!' Commit the Qur' an to memory and regularly recall it."'

b. Sa'd ibn 'Ubādah has quoted, "The Prophet of Islam has stated, 'Whoever memorises the Qur' an and then forgets it shall meet God as a leper on the Day of Resurrection."

c. The Prophet of Islam has stated, "All the rewards of my people were shown to me, even the reward for taking a straw out of a mosque. Further, all the sins of my people were shown to me, and I saw no sin greater than that of a person who had memorised a chapter or verse of the Qur' an and then forgot it" ('Āmilī, 1990, pp. 374-375). 
Considering these traditions, it is not possible to accept that the Prophet of Islam himself forgot parts of the Qur'an.

2) It would be the greatest of failings for the Prophet of Islam to forget a Qur' anic verse since, had he forgotten his miracle and the purpose of his mission, his message would no longer have been reliable. In this case, prophethood would have been beyond his competence. Could the Prophet of Islam have condemned others for an attribute he himself did not possesses? Since the Prophet of Islam is truly infallible, he cannot commit any errors or mistakes (Muzaffar, 1975, p. 415).

3) It is impossible that the Prophet of Islam could have forgotten any part of the Qur' an because of the divine promise to the contrary: "We shall have you recite [the Qur'an], then you will not forget [any of it]" (Q. 87:6; Makārim Shīrāzì, 1995, vol. 26, p. 393). In this verse, God states that this absence of forgetfulness is a blessing given by God in accordance with His will, and no power can cause forgetfulness or lack thereof if God does not will it because God is omnipotent ('Āmilī, 1990, p. 374; Maybudī, 1992, vol. 10, pp. 460-461; Ṭabrisī, 1993, vol. 10, p. 721; Ṭūsī, 1982, vol. 10, p. 330; Abū al-Futūḥ Rāzīi, 1987, vol. 20, p. 236).

4) The Qur' an is the core of the call to Islam. Even if one were to assume that the Prophet of Islam was capable of forgetting something, there is not even the slightest likelihood that this forgetfulness could exist with regard to the Qur'an which is fundamentally linked with his message.

5) Forgetfulness of Quranic verses by the Prophet of Islam would mean that he did not pay attention to requirements set by the Qur' an whereas no reasonable person would accept that the Prophet disregarded verses of the Qur'an ('Āmilī, 1990, pp. 375-376).

\section{Collection of the Qur'an after the Lifetime of the Prophet of Islam}

According to Juynboll, the Prophet of Islam did not collect the verses of the Qur' an in a single codex since this could have led to persistence of a verse even after its decree was abrogated (Juynboll, 2002, vol. 2, pp. 382-383).

This view is not justifiable. To explain, during the lifetime of the Prophet of Islam, the possibility of a decree being abrogated while the text of the verse persisted would not have been in conflict with the collection of the Qur' an since in the case of the abrogation of a decree and the continued existence of the related verse, it is the decree that is binding not the verse text itself, while in the collection of the Qur' an, it is the text that is important.

\section{The Chapters of Khal' and Ḥafd}

Juynboll mentions two chapters by the names of Khal' and Hafd, which were included in the muṣhaf (codex) of Ubayy ibn Ka'b, a well-known Companion (Juynboll, 2002, vol. 2, p. 385).

The great Companion, Ubayy ibn Ka'b, was falsely accused of adding two chapters, Khal' (lit. repudiation and renunciation) and Hafd (haste and competition), to the end of his Qur'anic codex.

These two chapters cannot be considered part of the Qur'an for a number of reasons.

1) Examination of the text of these two chapters demonstrates that they are inconsistent with the style and eloquence of the Qur'an. The structure of the verses is at variance with the structure of the Qur'an, and it is unreasonable to assume that a person such as Ubayy ibn Ka'b would not be aware of this ('Āmilī, 1990, p. 329; Ma 'rifat, 1990, p. 171; Rāmyār, 2001, p. 351; Balāghī, 1999, vol. 1, pp. 23-24).

2) It has never been claimed that these two chapters were submitted as part of the Qur'an during its collection. During the period of Abū Bakr, Ubayy ibn Ka'b personally participated in collection of the Qur'an. If he truly believed that these two chapters were part of the Qur'an, he should have presented them during collection of the Qur' an. In addition, the team appointed by 'Uthmān to collect the Qur' an transcribed only that which was a part of the Qur' an and put aside everything else including the chapters of Khal ' and Hafd. This also indicates that these chapters were not part of the Qur'an (Rāmyār, 2001, p. 350; Ma rifat, 1990, p. 172).

3) According to one narrative - which may or may not be correct-it seems that Khal and Hafd were supplications the Prophet of Islam entreated during ritual prayers. As it was customary at the time to write prayers at the end of the Qur'anic codex, Ubayy ibn Ka'b included these two chapters at the end of his (Ma' rifat, 1990, p. 171).

\section{The "Verse of Stoning" (rajm)}

Juynboll was of the opinion that a verse, which was called the "Verse of Stoning" and claimed to have been revealed to the Prophet of Islam, was later omitted from the 'Uthmānic codex (Juynboll, 2002, vol. 2, p. 385).

A number of issues must be considered concerning the "Verse of Stoning". 
1) There are varied accounts concerning the original text of the "Verse of Stoning". These differences indicate that the verse is not authentic (Khü' $\overline{1}, 1974$, pp. 220-221).

2) Examination of the text of the "Verse of Stoning" demonstrates that it is a weak composition, which in turn shows that it is not befitting of the holy Qur' an ('Āmilī, 1990, pp. 352; Balāghī, 1999, vol. 1, p. 22).

3) There is no verse in the Qur' an indicative of the decree of stoning, and if Islamic narratives discussing the "Verse of Stoning" are correct, it would indubitably mean that a verse has been omitted from the Qur' an. This would prove distortion of the extant Qur'an. However, using cogent arguments, scholars have proven that the Qur'an has not been distorted (Fakhr Rāzī, 2000, vol. 19, p. 123; Ṭabarī, 1992, vol. 14, p. 7; Tha 'labī Nīshābūrī, 2002, vol. 5, pp. 331-332; Ibn Kathīr, 1999, vol. 4, p. 453; Ma rifat, 1990, vol. 2, p. 145; Khū'î̀ 1974, p. 226; Jawādī Āmulī, 2011, vol. 1, p. 99).

4) Concerning the "Verse of Stoning", it was claimed that it was part of the Qur' an but that the text was abrogated while the Islamic decree necessitating stoning remained. This claim is tantamount to claiming distortion. Akhbār $\bar{a} h \bar{a} d$ (narratives from single transmitters) cannot be used as evidence in the issue of abrogation. There is consensus among Muslims that just as the Qur' an, in part or as a whole, cannot be validated by a narrative from a single transmitter, abrogation of the Qur'an cannot be established by such a narrative either. In addition to consensus among Muslims, it is the nature of sensitive and important topics to spread among the people very quickly. Therefore, the report of an important event through a narrative by a single transmitter itself proves that the event did not occur and that the transmitter either lied or made a mistake. When an important event occurs, many people report it and it becomes widely known among the people. Considering this, how can a narrative by a single transmitter prove that the "Verse of Stoning" was originally a Qur'anic verse that was omitted from the Qur' an while its decree remained valid? 'Umar ibn Khattāb asserted a statement as the "Verse of Stoning" claiming that it was part of the Qur'an. However, since he was the only one to quote this verse, the Muslims did not accept or include it in the Qur'an. Some scholars later claimed that the text of the verse was abrogated from the Qur'an while its decree remained (Khū' '̄ 1974, p. 304; Burūjirdī, 1996, p. 111).

5) It is reported that during the collection of the Qur' an after the time of the Prophet of Islam, 'Umar ibn Khattāa quoted the "Verse of Stoning" to Zayd ibn Thābit. However, Zayd did not accept the verse since "Umar was the only one to quote it and did not have any evidence to support his claim. This proves that the "Verse of Stoning" was not part of the Qur'an since the Prophet of Islam had scribes to write down verses when they were revealed. The Companions also had codices of the Qur'an that they had written during the period of the Prophet of Islam. Furthermore, many people had memorised the Qur' an during the period of the Prophet, and no part of the Qur' an had been lost. If the "Verse of Stoning" was actually a part of the Qur' an, why did not any of the Quranic scribes, Companions, or memorisers of the Qur' an validate 'Umar ibn Khațtāb's claim ('Āmilī, 1990, p. 348)?

6) The unanimity of the Companions in opposition to 'Umar's notion led him to doubt the verse. For this reason, even during his rule, he did not issue the command to add the "Verse of Stoning" to the Qur' an. The pretext that 'Umar's fear that the people would say he added something to the book of God prevented him is unreasonable since it is generally known that when 'Umar ibn Khațāb resolved to do something, fear of the people did not deter him. Thus, even the one who originally claimed that it was a verse of the Qur' an was not certain (Ma rifat, 1993, p. 162).

7) The following report completely undermines the idea of the decree of stoning as a Qur'anic verse. It is reported that 'Alī ibn Abī Țālib flogged Sharāhạh Hamdāniyyah on Thursday and stoned her on Friday. 'Alī declared, "I flogged her in accordance with the book of God and stoned her in accordance with the tradition (sunnah) of the Prophet of Islam". This report shows that the decree of stoning is a Prophetic tradition not a Qur'anic verse (Balāghī, 1999, vol. 1, p. 23).

8) Concerning the "Verse of Stoning", it is claimed that the text of such verse has been abrogated while its decree has remained valid. The following criticism is directed at this claim. The only way to prove a decree is through its text. Therefore, with the loss of the text, the decree is also rendered invalid. There does not seem to be any sense to invalidation of the text only. What is the benefit to abrogation of the text only while the decree persists ('Arīẹ, 1973, p. 224)? If benefit (mașlahat) necessitated the revelation of this verse and the verse covered a fixed religious decree, on what basis must the text of this verse be abrogated while benefit requires persistence of the text to act as evidence for the religious decree (Ma rifat, 1990, vol. 2, p. 287).

\section{Revelation of the Qur'an in Seven Readings}

Discussing revelation of the Qur' an in seven readings (qirā' $\bar{a} t$ or ahruf), Juynboll writes, "On various occasions the Prophet is supposed to have taught his followers one particular wording of a qur' ānic [sic] fragment at one 
time and at other times other wordings, concluding: '... recite it in the way that is easiest for you.' ...When 'Umar was once reported to have voiced his anxiety as to what is truly qur'annic [sic] and what not, the Prophet is said to have reassured him with the words: 'Every phrase that is purported to be part of the Qur'ann is correct as long as forgiveness...is not confused with chastisement...or chastisement with forgiveness,' and 'Each of the seven ahruf is 'sufficient and restores health' (käfin shäfin)."' (Juynboll, 2002, vol. 2, p. 385).

A number of issues must be noted concerning revelation of the Qur' an in seven readings. The most significant narratives in this regard are presented and discussed below.

1) Ibn 'Abbās quotes the Prophet of Islam as saying, "Gabriel presented the Qur' an to me in a single reading (harf), and I asked him to provide me with more. He provided further readings, and I asked him for more. He continued to increase them until there were seven readings" (Nīshābūrī, 1954, vol. 6, p. 101; Bukhārī, 1986, vol. 4, p. 555; Ṭabarī, 1992, vol. 1, p. 27).

2) Ubayy ibn Ka'b has stated, "I was in the mosque when a man entered and started praying. He performed his prayer with a reading that I did not favour. Then, another man entered and performed his prayer with yet another reading. Together, the three of us went to the Prophet of Islam. I said to the Prophet, 'This man came to the mosque and recited the Qur'an differently from the other.' The Prophet asked both of them to recite the Qur' an as they had. After they finished their recitation, the Prophet of Islam praised both of them. This outcome caused me to experience doubt. When the Prophet of Islam saw my distress, he placed his hand upon my chest, which was sweating profusely due to embarrassment. I felt as if in my fear I could see God. Then the Prophet stated, 'Ubayy ibn Ka'b! I was commanded to recite the Qur' an in a single manner. I requested ease for my people. The same command was repeated. Again, I requested ease for my people. The third time, I was commanded to recite the Qur'an in seven manners"' (Nīshābūrī, 1954, vol. 6, pp. 101-103; Ṭabarī, 1992, vol. 1, p. 32).

3) Ubayy ibn Ka'b has commented, "I entered the mosque and heard a man recite the Qur' an. I asked him, 'Who taught you the Qur'an?' He replied, 'The Prophet of Islam.' I took him to the Prophet of Islam and said, 'Ask this man to recite the Qur' an.' The man recited, and the Prophet declared, 'Good job!' I said, 'O Prophet of God! You taught me to recite the Qur' an like so...' He responded, 'Good job to you too!' I stated, 'O Prophet of God! Even though our readings differed, to both of us you say good job?' The Prophet placed his hand upon my chest and declared, 'Oh Lord! Remove doubt from the heart of Ubayy ibn Ka'b.' I was bathed in sweat from embarrassment and my whole body was suffused in fear and panic. Then, the Prophet of Islam stated, Two angels came to me. One of them said, 'Recite the Qur' an in a single manner.' But the other said, 'Increase the readings!' Therefore, I asked him to increase them. The angel said, 'Recite it in two ways.' And he continued increasing them until the readings numbered seven. Then, he said, 'Recite the Qur' an in seven readings"' (Tabarī, 1992, vol. 1, p. 29).

4) The Prophet of Islam has stated, 'Gabriel said, 'Recite the Qur' an in a single manner.' Michael said, 'Ask him to increase the readings.' Gabriel said, 'Recite it in two ways.' This continued until the readings numbered seven. Then he said, 'Each of these readings is sufficient on the condition that a verse of punishment is not recited as a verse of mercy and a verse of mercy is not changed into a verse of punishment"' (Ibid, p. 38).

5) 'Umar ibn Khaț̣āb has stated, "I heard Hishām ibn Ḥukaym reciting the chapter of Furqān. I listened to his reading. Upon realising that he recited the Qur' an in a way that the Prophet of Islam had not taught me, I hastened toward the man, who was engaged in prayer. I waited patiently for him to pray. When he finished his prayer, I clutched his collar and asked, 'Who taught you to recite this chapter in this manner?' In response, he claimed that the Prophet of Islam had taught him so. I declared, 'By God, you are lying!' I dragged him to the Prophet of Islam. I said to the Prophet, 'Hishām ibn Hukaym recites the chapter of Furqān in a way that you have not taught me.' The Prophet of Islam said, 'O Hishām ibn Hukaym! Recite this chapter!' He recited it in the way that I had previously heard from him. The Prophet of Islam stated, 'This reading has been revealed in this manner.' Then he asked, 'Umar ibn Khațāab, recite!' I recited in the manner that the Prophet of Islam had taught me. The Prophet stated, 'It is correct. This reading has been revealed in this manner. The Qur' an has been revealed with seven readings. Therefore, recite as much [of the Qur'an] as you can"' (Bukhārī, 1986, vol. 3, p. 257; Nīshābūrī, 1954, vol. 6, pp. 98-99; Tirmidhī, 1987, vol. 5, pp. 177-178).

6) Ubayy ibn Ka'b has commented, "One day, the Prophet was beside the pond of Banī Ghaffăr. Gabriel came to him and said, 'God commands you to teach your people the Qur' an with a single reading.' The Prophet of Islam said, 'I ask God for forgiveness and tolerance. My people are not capable of doing this.' Gabriel came to him a second time and said, 'God commands you to teach your people the Qur' an with two readings.' The Prophet of Islam said, 'I ask God for forgiveness and tolerance. My people are not capable of doing this.' Then, Gabriel came to him a third time and said, 'God commands you to teach your people the Qur'an with three readings.' 
Again, the Prophet of Islam said, 'I ask God for forgiveness and tolerance. My people are not capable of doing this.' Then, Gabriel came to him a fourth time and said, 'God commands you to teach your people the Qur' an with seven readings. Any of these seven readings that they use is sufficient and correct"' (Nīshābūrī, 1954, vol. 6, pp. 103-104; Tabarī, 1992, vol. 1, p. 35).

7) Ubayy ibn Ka'b has stated, "The Prophet of Islam met Gabriel near Ahjār al-Mirā'. The Prophet stated, 'I have been appointed to an illiterate people composed of youths, servants, and old men and women.' Gabriel replied, 'Thus, let them recite the Qur' an in seven readings"' (Ṭabarī, 1992, vol. 1, p. 31).

8) Abū Hurayrah has reported, "The Prophet of Islam stated, 'This Qur' an has been revealed in seven readings. Therefore, you can recite it in any of these seven readings and there is no problem. Just pay attention that you do not alter a verse of mercy to a verse of punishment or a verse of punishment to a verse of mercy!"' (Ibid, p. 40).

9) 'Abd Allāh ibn Mas' ūd has commented, "We had a debate about the number of verses in one of the chapters of the Qur' an - whether there were 35 verses in it or 36. We all went to the Prophet of Islam. He was engaged in a secret discussion with 'Alī ibn Abī Tâalib. We said, 'O Prophet of God! We have differences in our recitation of the Qur'an.' The Prophet's face turned red in anger and he said, 'Truly, past nations were destroyed due to differences that arose among them!' He then quietly said something to 'Alī ibn Abī Taallib, who then said to us, 'The Prophet of Islam commands you to recite the Qur' an as he has taught you"' (Ibid, p. 23).

10) Ubayy ibn Ka'b has reported, “The Prophet of Islam stated, 'O Ubayy ibn Ka'b! I recited the Qur' an, and I was asked, 'With one reading or two?' The angel that was before me said, 'Say: with two readings.' Then, I was asked, 'With two readings or three?' The angel that was with me said, 'Say: with three readings.' Similar questions were repeated until seven readings was reached. Then, I was told, 'It is sufficient to recite the Qur' an in any of these readings on the condition that a verse of punishment is not confused with a verse of mercy and a verse of mercy is not confused with a verse of punishment"' (Qurțubī, 1999, vol. 1, pp. 32-33; Abū Dāwūd Sajistānī, 1952, vol. 2, p. 102).

\subsection{A Number of Criticisms Apply to These Accounts}

1) Contradictions exist among narratives concerning revelation of the Qur'an in seven readings (Mu'addab, 2008, p. 46). Some of these contradictions are as follows.

a. Some narratives in this regard indicate that Gabriel recited a single reading of the Qur'an for the Prophet of Islam. The Prophet asked Gabriel that recitation of the Qur' an not be limited to one reading. Thus, Gabriel increased the readings until they reached seven. Some of these narratives indicate that the increase in readings was gradual whereas others state matters differently. Some of them report that after the third request of the Prophet, the number of readings was immediately increased to seven while according to other narratives, after the Prophet of Islam's third request, God commanded him to recite the Qur' an with three readings, and after the fourth request, God commanded him to recite the Qur' an with seven readings.

b. Some of these narratives indicate that the increase in number of readings occurred in a single sitting such that the angel Michael advised the Prophet to ask for additional readings and Gabriel continually increased to them until it reached seven readings. However, in other narratives, every time the Prophet of Islam asked for additional readings, Gabriel would leave and return until seven readings was reached.

c. Some narratives report that Ubayy ibn Ka'b entered the mosque and saw a man reciting the Qur'an differently from him, but others state that Ubayy ibn Ka'b was already in the mosque when two men entered and recited the Qur' an differently.

2) In the ninth narrative, transmitted by 'Abd Allāh ibn Mas'ūd, the question and answer lack congruity. According to the narrative, 'Abd Allāh ibn Mas' ūd and a group of others had a difference of opinion regarding the number of verses in a chapter of the Qur' an. They took their dispute to the Prophet of Islam. 'Ali ibn Abi Ṭālib, who was beside the Prophet, declared, "The Prophet of Islam commands you to recite the Qur' an as he has taught you." Obviously, this response is inconsistent with the question of 'Abd Allāh ibn Mas 'ūd and those who were with him. Additionally, this response does not provide a solution to their problem $\left(\mathrm{Khu}_{\bar{u}}^{\prime} \mathbf{1}, 1974\right.$, pp. 194-195).

3) These narratives suggest that the reason for the multiplicity of readings was to make the job of Muslims easier since all Muslims could not recite the Qur' an with a single style and reading. With this in mind, the Prophet of Islam asked God to increase the readings of the Qur' an for Muslims which led to the sevenfold readings. However, the existence of multiple readings did not make anything easier upon the Muslims, but rather caused confusion, trouble, and division to the extent that some Muslims denounced (takfir) others as unbelievers. This eventually led 'Uthmān to limit the Qur' an to a single reading and burn other Qur' ans that caused conflict among 
Muslims. Thus, difference in readings of the Qur'an was in fact a calamity for the Islamic community, which manifested itself in the time of 'Uthmān. How can it be said that the Prophet of Islam asked God for something that led to corruption and dispute within the Islamic community? How is it possible for God the All Wise to accept such a request while many Qur'anic verses and Islamic narratives prohibit dispute? (Ṭabātabā'̄ $\mathbf{1}, 1996$, vol 3, p. 369; Sūyūṭ̂i, 1983, vol. 2, pp. 60-61; Kāshānī, 1954, vol. 2, pp. 285-287; 'Arūsī Ḥuwayzī, 1991, vol. 1, pp. 377-378; Tayyib, 1999, vol. 3, p. 303). Dispute leads to destruction of the community, and some Islamic narratives indicate that when the matter of difference in readings was discussed in the presence of the Prophet of Islam, his face would turn red.

4) According to narratives concerning revelation of the Qur' an in seven readings, the reason the Prophet of Islam provided for the increase of readings was that his followers did not have the ability to recite the Qur'an with a single reading. This is absolutely false, and it is unreasonable to attribute such statements to the Prophet of Islam. After the period of 'Uthmān, Muslims were able to recite the Qur' an with a single method despite their vast differences in language and race. Hence, how can one claim that in the period of the Prophet of Islam, when the Islamic community was composed of fluent speakers of Arabic, one method of reading was difficult? (Khü' $\overline{\text {, }}$ 1974, pp. 198-199; 'Āmilī, 1990, p. 182)

5) 'Uthmān forced a single reading upon the Muslims and great Companions such as 'Alī ibn Abī Ṭālib endorsed this act (Hujjatī, 2006, p. 444). If the Qur' an was truly revealed with seven readings, it would be appropriate for great Companions such as 'Alī ibn Abī Țâlib to object to this measure by 'Uthmān on the basis of narratives of sevenfold readings. The fact that they did not confirms the falseness of the sevenfold readings ('Āmilī, 1990, p. 181).

6) Basically, the idea of revelation of the Qur' an in seven readings is unreasonable and futile. By examining such narratives, nothing useful is achieved (Khü' $\overline{1}, 1974$, p. 195).

\section{Distortion of the Qur'an}

Juynboll has written, "Among the better known examples of instances where the Shī' ites accuse the Sunnites of having introduced alterations ( $t a$ ' $r \bar{i} f \bar{a} t$ ) in the final redaction of the Qur' ān is the suppression of the word $a^{\prime}$ 'imma, the plural of imäm, and substituting for it umma, "community"' (Juynboll, 2002: vol. 2, p. 396).

With the aid of a number of Companions of the Prophet of Islam, 'Uthmān ibn 'Affān, the third caliph, collected the final version of the Qur' an, and sent manuscripts to the two important regions of the Islamic empire (Ibn Ḥajar 'Asqalān̄̄, 2000, vol. 9, pp. 15-18; Ibn Abī Dāwūd Sajistānī, 2004, p. 34; Zarkishī, 1956, vol. 1, p. 240). However, omission of a term and its replacement with another term in the final version of the Qur'an-in other words, belief in distortion of the Qur' an - cannot be accepted due to the following reasons.

1) During the incumbency of 'Uthmān, Islam had developed to such an extent that it was not possible for 'Uthmān or anyone else to change any part of the Qur' an (Khū'î, 1974, p. 237).

2) When 'Uthmān insisted that a word from verse 9:34 be omitted, Ubayy ibn Ka'b strongly objected and even threatened 'Uthmān that he would draw his sword and fight. 'Uthmān was forced to withdraw his opinion (Suyūṭ̂, 1983, vol. 3, p. 419). Considering this, how is it possible for 'Uthmān to delete a word from the Qur' an and replace it with another without any of the Companions protesting?

3) If 'Uthmān had distorted the Qur'an, it would have been a very apposite excuse for those who wished to murder him. If this case had been true, they would not have needed to use the pretexts that 'Uthmān violated the traditions of Abū Bakr and 'Umar and squandered the public treasury among others in order to openly murder him.

4) If the Qur' an had been distorted by 'Uthmān, when 'Alī ibn Abī Țālib became caliph, he would have changed it back to the way it was recited in the time of the Prophet of Islam, Abū Bakr, and 'Umar. Such an act would not have been criticised or protested by anyone. In fact, it would have been clear proof against his opposition, the supporters of 'Uthmān. Thus, the silence of 'Alī ibn Abī Țâlib concerning the version of the Qur'an that was widespread among the Muslims during his rule is proof of the fact that there was no distortion in it (Khü' $\mathbf{1}, 1974$, pp. 237-238).

\section{Conclusion}

Juynboll believed that Muhammad, the Prophet of Islam, forgot parts of the Qur' an and that he did not gather the entire Qur' an into a single codex during his lifetime due to the possibility that the Qur'anic text would remain even after its related decree was abrogated. Juynboll was of the opinion that the Qur' an had been distorted. Specifically, he was convinced that the "Verse of Stoning", which is not included in the extant Qur' an, was part 
of the Qur'an. Furthermore, he accused the Shia of believing in the distortion of the Qur'an, with the term a' immah having been replaced with the term ummah. Examination of the views of Juynboll concerning Qur' anic sciences indicates that he performed significant research in Islamic sources. However, his undeniable mistakes demonstrate that he either did not have all reliable Islamic sources available to him or was not aware of them. Due to Juynboll's use of unreliable Islamic narratives, his opinions concerning Qur' anic sciences are weak.

\section{References}

Abū al-Futūḥ Rāzī, Ḥ. (1987). Raw ạ al-Jinān wa Rūh al-Jinān fì Tafsìr al-Qur'ān. Mashhad: Bunyād-i Pizhūhish-hā-yi Islāmī-yi Āstān-i Quds-i Raḍawī.

Abū Dāwūd Sajistānī, S. (1952). Sunan Abī Dāwūd. Cairo: Muștafā Albābī al-Ḥalabī.

'Āmilī, J. (1990). Haqā' iq Hāmah Hawl al-Qur'ān al-Karīm. Qum: Mu' assisat al-Nashr al-Islāmī.

'Arị̄, 'A. (1973). Fath al-Mannān fì Naskh al-Qur'ān, Cairo: Maktabat al-Khānjī.

'Arūsī Ḥuwayzī, 'A. (1991). Tafsīr Nūr al-Thaqalayn. Qum: Manshūrāt-i Ismā̄ îliyyān.

Balāghī, M. (1999). Ālā' al-Rahmmān fì Tafsìr al-Qur' ān. Beirut: Dār al-Ihyyā’ al-Turāth al- 'Arabī.

Bukhārī, M. (1986). Șaḥ̄ḥ al-Bukhārī. Beirut: Dār al-Qalam.

Burūjirdī, M. (1996). Burhān-i Rawshan. Tehran: Kitāb Furūshī-yi Būdhar Jumehrī (Muștafawī).

Fakhr Rāzī, M. (2000). Mafātīh al-Ghayb. Beirut: Dār al-Iḥyā’' al-Turāth al-'Arabī.

Ḥujjatī, M. (2006). Pazhūhishī dar Tārīkh-i Qur'ān-i Karīm. Tehran: Daftar-i Nashr-i Farhang-i Islāmī.

Ibn Abī Dāwūd Sajistān̄̄, 'A. (2004). Kitāb al-Mașāhiff. Damascus: Dār al-Takwīn li-al-Nashr wa al-Tawzī' .

Ibn Ḥajar 'Asqalān̄i, A. (2000). Fath al-Bārī. Riyadh: Dār al-Salām.

Ibn Kathīr, I. (1999). Tafsìr al-Qur'ān al- 'azīm. Beirut: Dār al-Kutub al- 'Ilmiyyah.

Jawādī Āmulī, 'A. (2011). Tasnīm. Qum: Mu'assisah Isrā' .

Juynboll, G. H. A. (2002). 'Hadith and the qur'an', Encyclopaedia of the Qurān, Leiden: Brill.

Kāshānī, M. (1954). Tafsīr Manhaj al-Sāadiqīn fì Ilzām al-Mukhālifìn. Tehran: Kitābfurūshī-yi Muḥammad Ḥasan 'Elmī.

Khū'î, A. (1974). al-Bayān fì tafsìr al-Qur'ān. Qum: al-Maṭba 'at al- 'Ilmiyyah.

Makārim Shīrāzī, N. (1995). Tafsìr-i Nimūnah. Tehran: Dār al-Kutub al-Islāmiyyah.

Ma'rafah, M. (1990). al-Tamhīd fì 'Ulūm al-Qur'ān. Qum: Markaz-i Mudīriyat-i Ḥawzah-yi 'Ilmiyyah-yi Qum.

Idem. (1993). Siyānat al-Qur'ān min al-Tahrīf. Qum: Mu' assisat al-Nashr al-Islāmī.

Maybudī, R. (1992). Kashf al-Asrār wa 'Udah al-Abrār. Tehran: Amīr Kabīr.

Mu'addab, R. (2008). Nuzūl-i Qur'ān va Ru'yā-yi Haft Harf. Qum: Būstān-i Kitāb.

Muẓaffar, M. (1975). Dalā'il al-Ṣidq. Qum: Manshūrāt Maktabah Bașīratī.

Niyshābūrī, M. (1954). al-Jāmi ' al-Ṣaḥ̄hh. Beirut: Dār al-Iḥyā’ al-Turāth al- 'Arabī.

Qurțubī, M. (1999). al-Jāmi' li-Aḥk̄m al-Qur'ān. Beirut: Dār al-Kutub al- 'Ilmiyyah.

Rāmyār, M. (2001). Tārīkh-i Qur'ān. Tehran: Intishārāt-i Amīr Kabīr.

Rezaee Haftador, H. (2015). Examination of the Ascension of the Prophet of Islam in the View of Orientalists. Review of European Studies, 3.

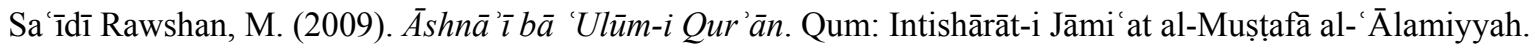

Suyūṭī, J. (1983). al-Durr al-Manthūr fì al-Tafsìr bi-al-Ma'thūr. Qum: Manshūrāt Maktabah Āyat Allāh al- 'Uḍmā al-Mar' ashī al-Najafī.

Ṭabarī, M. (1992). Jāmi' al-Bayān 'an Ta'wōl Āy al-Qur'ān. Beirut: Dār al-Ma rifah.

Ṭabāțabā' î̀, M. (1996). al-Mīzān fì Tafsìr al-Qur'ān. Qum: Daftar-i Intishārāt-i Islāmī.

Ṭabrisī, F. (1993). Majma 'al-Bayān li- 'ulūm al-Qur'ān. Tehran: Nāṣir Khusraw.

Ṭayyib, 'A. (1999). Atyab al-Bayān fì Tafsīr al-Qur'ān. Tehran: Intishārāt-i Islām.

Tha 'labī Niyshābūrī, A. (2002). al-Kashf wa al-Bayān 'an Tafsīr al-Qur'ān. Beirut: Dār al-Ihyyā' al-Turāth al-'Arabī. 
Tirmidhī, M. (1987). al-Jāmi ' al-Sahịhh. Beirut: Dār al-Kutub al- 'Ilmiyyah.

Ṭūsī, M. (1982). al-Tibyān fì Tafsìr al-Qur'ān. Beirut: Dār al-Ihyaā' al-Turāth al-'Arabī.

Zarkishī, B. (1956). al-Burhān fì 'Ulūm al-Qur'ān. Beirut: Dār al-Ihyāa' al-Kutub al-'Arabiyyah.

Zarqān̄̄, M. (1995). Manāhil al- 'Irfān fì 'Ulūm al-Qur'ān. Beirut: Dār al-Kutub al- 'Ilmiyyah.

\section{Copyrights}

Copyright for this article is retained by the author(s), with first publication rights granted to the journal.

This is an open-access article distributed under the terms and conditions of the Creative Commons Attribution license (http://creativecommons.org/licenses/by/3.0/). 